\title{
A Case of Von Recklinghausen's Neurofibromatosis
}

\section{Dr. Salvador Labrador Descalzo ${ }^{1 *}$, Dr. Ana Maria Salas-Martinez ${ }^{2}$}

${ }^{1}$ Health Center of Guriezo, Cantabria, Servicio Cantabro de Salud (Public Health System in Cantabria). Spain.

${ }^{2}$ Dermatology Department, Hospital de Sierrallana, Torrelavega, Cantabria, Spain. salvadorlabrador@hotmail.com

*Corresponding Author: Dr. Salvador Labrador Descalzo, Health Center of Guriezo, Cantabria, Servicio Cantabro de Salud (Public Health System in Cantabria). Spain.

A young male presented at our clinic for routine consultation. Multiple skin nodules were observed on the face and hypo pigmented macules on the dorsum of both hands. We examined the patient and skin nodules between 2 and 15 milimeters appeared on his trunk, abdomen, upper limbs, dorsal and lumbar regions. (Panel A and B). Scoliosis of the vertebral spine and several "café au lait" macules along with axillary freckling were present in several body areas. (Panel B). This clinical picture depicts a well known medical $^{(2)}$ disorder such as Neurofibromatosis type 1 ,

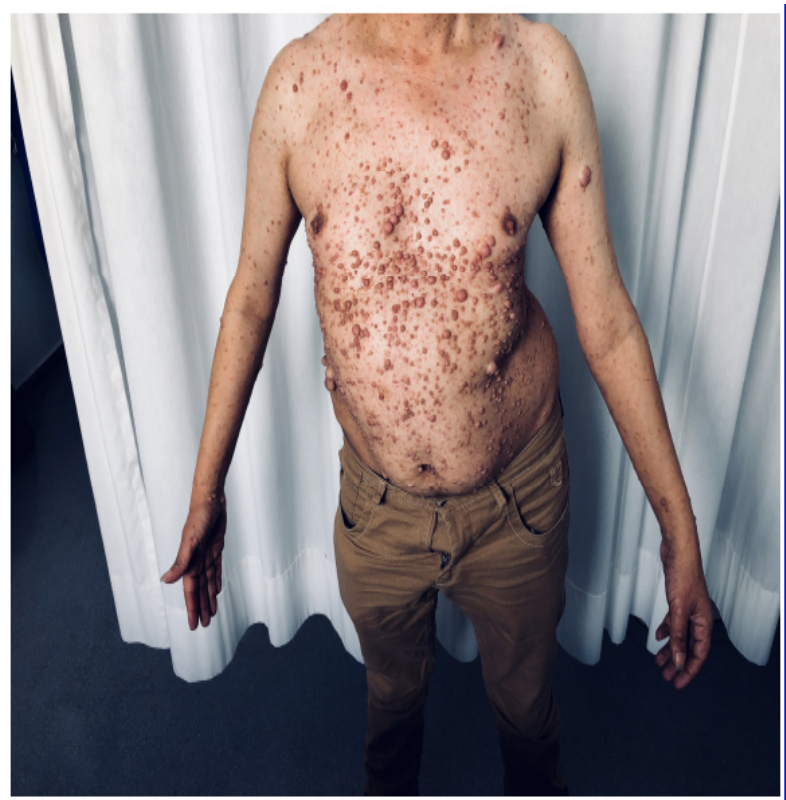

a Neurocutaneous syndrome caused by neurogenic tumors arising from neural sheath cells located along peripheral and cranial nerves. ${ }^{(3)}{ }^{(1)}$ Neurofibromatosis type 1, also known as Von Recklinghausen disease, is an inherited autosomal dominant disorder with an incidence of 1 in 3000 . NF type 1 is the most prevalent type (90 per cent of all cases) and it is caused by mutations of the NF1 gene located at chromosome 17 (q 11.2) and coding for a tumor suppressor gene, neurofibromin. ${ }^{(4)}$ These patients should be offered genetic counseling and scheduled for regular follow-ups. ${ }^{(5)}$

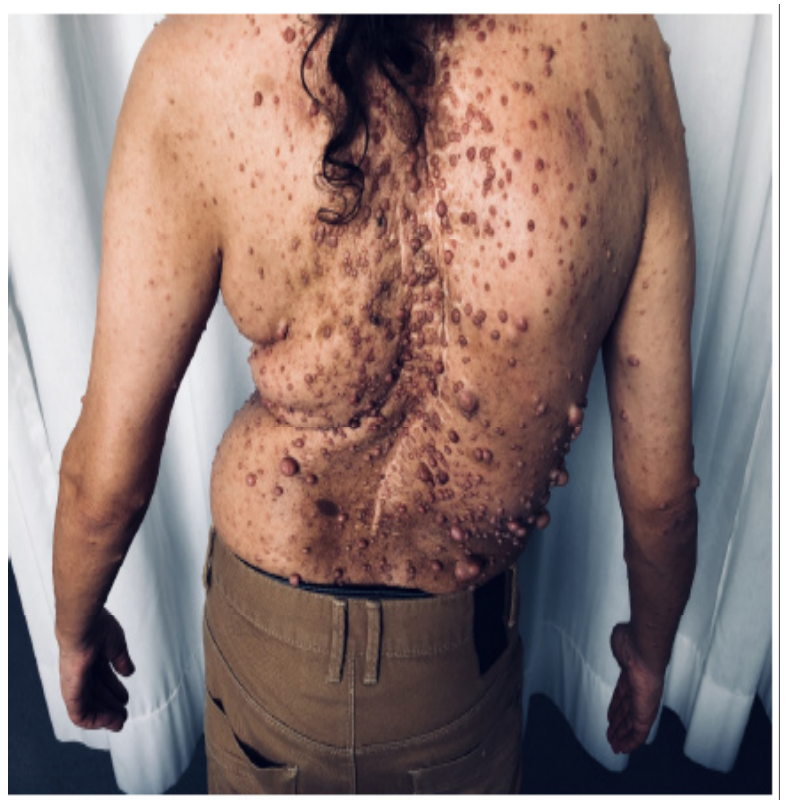

\section{Informed Consent and Conflict of Interest}

We obtained a verbal informed consent from the patient for continuing medical education purposes and reflected on his Medical file.

The author declares having no conflict of interest. 
A Case of Von Recklinghausen's Neurofibromatosis

REFERENCES $\quad$ Neurocutaneous Syndromes. Medicine 1998;

[1] Riccardi VM. Von Recklinghausen's 7(92):4283-90. (In Spanish)

Neurofibromatosis. N Eng J Med. 1981; 305(25): 1617-27.

[2] Cohen PR. Neurofibromatosis Type 1. N Eng J Med. 1993; 329: 1549.

[4] Marcdante KJ, Kliegman RM. Nelson essentials of pediatrics. Elsevier-Saundres 6 th Edition. 2011; 186: 707-8.

[3] Gonzalez-Martin R, Ramos-carillo F.

[5] Gobernado JM. Primary Brain Tumors. Medicine. 1986; (66): 2713-27. (In Spanish).

Citation: Dr. Salvador Labrador Descalzo, Dr. Ana Maria Salas-Martinez. A Case of Von Recklinghausen's Neurofibromatosis. Archives of Dermatology and Skin Care. 2019; 2(1): 18-19.

Copyright: (C) 2019 Dr. Salvador Labrador Descalzo, Dr. Ana Maria Salas-Martinez. This is an open access article distributed under the Creative Commons Attribution License, which permits unrestricted use, distribution, and reproduction in any medium, provided the original work is properly cited. 